\title{
Role of Financial Banks in Promoting the Entrepreneurship: A Mixed Methodology Approach from Kingdom of Saudi Arabia
}

\author{
Abdullah Mohammed Aldakhil ${ }^{1}$, Muhammad Moinuddin Qazi Abro ${ }^{1}$, Muhammad Adnan Khurshid ${ }^{1}$ \& Alamzeb \\ Aamir $^{1}$ \\ ${ }^{1}$ Department of Management, College of Business Administration, King Saud University, Riyadh, Kingdom of \\ Saudi Arabia \\ Correspondence: Dr. Muhammad Moinuddin Qazi Abro, Assistant Professor, Department of Management, College \\ of Business Administration, King Saud University, Riyadh, Kingdom of Saudi Arabia
}

Received: November 11, 2014

Accepted: August 25, $2015 \quad$ Online Published: September 4, 2015

doi:10.5430/ijfr.v6n4p114

URL: http://dx.doi.org/10.5430/ijfr.v6n4p114

\begin{abstract}
The issue of getting finances for the small businesses and entrepreneurs is always been in debate and remain unresolved in many countries due to unavailability of qualified venture capitalists. The developing and emerging economies set the micro finance banks for this purpose, however, it is argued that the owner and entrepreneur faces many problems like collaterals, documentation, etc. This research focuses on the role of financial banks in promoting the small business and entrepreneurial culture in the Saudi Arabia in providing credit. The research applied a mixed methodology and at the first stage, qualitative data is collected and then the results of these structured interviews were used to construct a survey questionnaire for the quantitative analysis. The result of study shows that the levels of business cooperation and information sharing and quality of business have an important significance on the success of loan application. Furthermore, the results also support that the bureaucracy of bank in terms of loan documents requirement and loan evaluation procedure can make small business hesitate when applying for loans.
\end{abstract}

Keywords: financial banks, small and medium enterprises, entrepreneurship, Saudi Arabia

\section{Introduction}

The effective and efficient supply of finance to the small business sector has been seen as one of the most important influence on its success. Different theories suggest that small business sector in evolving economies faces greater credit constraint than those in developed economies (Jane, S. Pollard, 2003). However, there are limited studies of credit gap for small businesses and entrepreneurs in the gulf countries. In this situation, a study of the nature of credit gap between commercial banks and small businesses/entrepreneurs is of great significance in terms of theoretical contributions and policy implications. However, in order to analyse the problem, the selection of a valid and accurate measurement is important to ensure the quality of research findings. But this is not a simple task and depends much on the possibility of information access, especially when the measurement is based on abstract and intangible constructs, such as the perceptions of bank manager and business owner's/ entrepreneurs points of view (Lawrence et al, 2000).

The purpose of this paper is to measure the credit constraint of small business/ entrepreneurs sector in the Saudi Arabia. Applying mixed data collection methods, the study focuses on the problem of bank finance access faced by small businesses/ entrepreneurs, which is one of the most important factors in determining the success of business. In the data collection phase, qualitative data was collected through the structured interview with bank managers. The findings of the structured interviews are used to construct and validate the questionnaire survey of small business owners in the second phase of data collection.

\section{Literature Review}

The concept of market failure in economics denotes a situation in which goods or services are not made available to those demanding them at the lowest social cost (Jean and Jean, 2006). The market failure occurs, when the Pareto conditions fail. Cressy (2002) argued that funding gap is a phenomenon of market failure that can result in a related outcome, called credit rationing. It could be said that market failure of finance provision occurs when the funding supply and funding demand cannot be matched due to the malfunction of the capital market. 
Generally, market failure in finance provision can arise from the behaviour of finance suppliers or finance demanders in market. Supply-side market failure in finance occurs as financial institutions reject the finance proposal for the reasons which are not related to the projected rate of return. In other words, market failure of finance provision occurs when finance is refused for the projects that can be expected to be profitable. The lender's main criteria usually relate to features of the project to be funded, including market demand, production cost, and management adaptability, rates of return and risk and uncertainty levels. In contrast, Demand-side market failure in finance provision occurs when firms cannot properly access the financial opportunities available due to lack of knowledge, poor management, and poor presentation of proposals. Furthermore, the problems of market failure in finance provision can be related to such commercial criteria as lack of record, lack of security for loan, poor business location, type of firm, industrial sector, type of entrepreneur, poor past financial record, rapid expansion and high level of risk (Alain Fayolle and Kiril Todorov, 2011). In this situation, information can play an important role in reducing the level of market failure in the credit market. Therefore, understanding of asymmetric information nature can reduce the information gap between lender and borrower, and this can result in reducing the level of credit finance gap for small business/ entrepreneurs in the capital market (Allen and Engert, 2007).

The current theories suggest that both small business sector in emerging economies and small business sector in mature market economies encounter the problem of finance supply due to the asymmetry of information. Muhsin and his colleagues investigate the causality between financial development and economic growth for Middle East and North African countries and found no causality between financial development and economic growth for all the measured financial indicators (Muhsin, Kar et al, 2011). However, the empirical studies show that the extent of finance gap caused by information asymmetry is likely to be greater for small businesses in transition economies than those in mature market economies (Vos, E et al, 2007). The reason for this is that in mature markets the capital market in terms of debt and equity finance is better developed and supported by an effective legal framework. This can reduce the level of information problem and increase the reliability level of information exchange between partners in the capital market. Additionally, it is clear that the development of supporting market institutions in developed economies can effectively help small businesses to get more opportunity to access different sources of finance than those in transition (Smallbone \& Welter, 2001) and developing economies (Aryeetey, 2008), and the high level of development of banking system can also reduce the level of asymmetric information in the credit market.

Unlike small business sector in developed market economies, small businesses in transition and developing countries operate their businesses in an ineffective supporting environment because of the lack of effective legal framework, poor information transparency, bureaucracy and corruption, but lack of finance can be seen as the most serious problem. Small business sector in Saudi Arabia is not an exception, the large majority of small businesses face the shortage of finance for foundation and development, but they find it difficult to access credit fund from commercial banks. Types of finance rather than bank credit are nonexistent or infant in the capital market. Information asymmetry and the attitude of state commercial banks toward private sector; particularly small business sector can create a major barrier for small businesses to access finance to support their foundation and future growth (Webster, 2009).

Much evidence suggests that the private sector, especially small business, plays a dynamic role in many emerging countries as they have moved from central planning to market economies. However, behaviour of small business sector has not been well-understood yet, especially in Saudi Arabia market economies (Landier, A. and D. Thesmar, 2009). It is believed that small business sector in Saudi Arabia encounters more economic, institutional and legal obstacles than those in mature market economies in terms of finance access, legal and regulatory restrictions, poor infrastructure, and shortage of managerial and technical expertise. Therefore, it is important at this stage to analyse these issues and collect the both theoretical and empirical evidences.

\section{Data Collection}

\subsection{Qualitative Approach: Structured Interview}

The qualitative method is used when the researchers wish to be closer to organisational members in order to gain the sort of insights into people and situations they require for their research (Silverman, 2011). Generally, interpretivism researchers use qualitative method to understand the way people construct their reality On the other hand; positivism researchers also use qualitative method in data collection phase in order to gain greater understanding of their studies. The label 'qualitative interview' has been used to describe a broad range of different types of interview, from those that are totally non directive or open to those that are prepared as a list of questions that interviewers intend to ask in the interview. In fact, depending the purpose of the research and related information required by analysis in the 
research, interviews can be in forms of structured interview (standardised), unstructured interview (non-standardised), and partially-structured interview (Silverman, 2011). The structured interview is design to collect the same data from each respondent in the research sample. In structured interview or partially structured interview, the interviewer prepare the list of question or interview guide depending on the purpose of data collection in order to direct the interview on a path consistent with the purpose of the research.

The interview guides can provide the topic or subject area that the interviewer can feel free to explore, probe and ask question (Michael Quinn Patton, 2001). Furthermore, the interview guides can be developed more or less relying not only on the researcher's ability to address and specify the important issues, but also on the limited time available and particular situation as the interview is carried out. Through probes, follow-up questions and attention to non-verbal cues, the researcher can validate the data collected. Hakim (1987) argued that interview technique shows quite good validity in term of research strategy. It provides more complete and more accurate information than other techniques. However, this method also shows the limitation because the subjective bias of the interviewer can have an influence on the interpretation of the data collection, but this limitation may be more likely with the unstructured interview than with structured interview. In this study, a structured interview is carried out to collect qualitative data from the commercial bank managers in order to serve the purpose of constructing and validating the questionnaire in the next phase of quantitative data collection. The interview guide prepared in which the major issues or questions of the research are able to be addressed and asked in the interview within time and setting limitations.

To help construct proper questions in the survey questionnaire, fifteen structured interviews of local commercial bank managers have been carried out. Together with issues mentioned in current theories, the guidelines of structured interview focussed on such following critical problems that might hinder the possibility of small businesses accessing bank credit as business cooperation with bank, quality of business, transparency of business information, quality of bank services, bureaucracy of commercial bank, property rights and equality of credit access. Each interview lasted approximately one hour and a half in average, and the interviews were conducted with the credit managers of the local commercial banks, and the key results of the interviews can be summarised as follows:

- The credit managers interviewed agreed that collateral was a key issue in evaluating loan application, and most small businesses used land and houses as collateral for their loan application at local commercial banks. Loan applications were only considered by credit officials when the documents that confirm the legal possession of collateral were recognised by local authorities. Managers were aware of the problems created by inadequate specification of property rights, especially as a manager explained that the determination procedure for property rights was complicated and bureaucratic. Furthermore, the regulations are brief, unclear and ambiguous. As a result, it takes so much time, expenses and efforts for small business owners to get the certificate that approved their own legal possession of assets. In case of failure to submit the legal documents that prove legal possession of property, or even the determination of legal possession of assets in progress, commercial banks have to reject loan applications. It is likely that when the determination procedure of legal property rights is simplified, the possibility of credit access for small business can be increased significantly.

- Bank relationship can be discussed from both sides in term of quality of bank services and business cooperation with bank. Generally, managers noted that such transaction as bank loan is much dependent on information between two partners in the contract, and they recognised that information plays an important role in the loan evaluation process. A better understanding and information exchange between local commercial banks and small businesses can improve the quality of information and increase the reliability on the information of business performance and financial statements, and as result this can reduce the risk of bank loan. However, the managers admitted that the relationship between commercial banks and small businesses is far in terms of business cooperation and information sharing. Additionally, a manager noted that a large number of young small businesses start their businesses with unclear purposes, strategies and visions, and especially they have no previous transactions with bank. Therefore, banks have no any evidence of their credit histories, as a result without loan securities; their loan applications are being rejected. Moreover, managers also recognised that until now there was no information centre where the credit transactions of the businesses was recorded, so banks could share information of business credit records. And therefore asymmetric information problem forced commercial banks to protect themselves by rejecting applications without loan securities, a credit manager of local commercial bank commented.

- In general, managers interviewed agreed that the main objective of state commercial banks was profit, and provided credit to all economic sectors in economy. However, they admitted that state commercial banks had more favourable conditions for the state sector when loan securities were not a compulsory requirement. A manager explained that it was quite understandable that both legal and working capital for state commercial bank's activities came from state 
budget, but the state sector contributed a high share in total national gross domestic product and budget revenue as well. In other words, it could be said that both state enterprise and state commercial banks got the subsidies from the state budget. Under condition of soft budget constraint, state commercial banks had to follow the administrative commands from local authorities to offer loan proposed by state enterprises without any securities. In case of project failure, state commercial banks could cover their losses by additional subsidies from local state budget. But the situation was different when state commercial banks deal with loan application from the private small businesses. In case of project failure, the commercial banks lost their capital, the responsibility of bank managers was considerable, and there was no subsidy for these losses. That was the reason why state commercial banks had to be much more cautious when deciding to lend money to private sector, especially small businesses, and the documents and other requirements for loan were also much higher and stricter when compared with the state enterprises, a credit manager explained.

- Mangers realised that quality of business in terms of business performance and business records has an important impact on lending decision of commercial bank. A good business performance in the past can give bank manager a considerable evidence for the loan application of future project. According to asymmetric information problem, when collateral was used as an effective tool to reduce the risk of loan, such conditions as ability of asset liquidity and debt-equity ratio in capital structure were considered thoroughly by bank managers when they make lending decisions. It could be seen that the lower the level of asset liquidity, the higher the level of loan rejection. Furthermore, other conditions such as credit history with banks and other businesses, business cooperation and information sharing were also considered when bank managers accept or reject loan applications from small businesses. It could be said that such small businesses had good business performances, transparent business records, clear credit histories and potential projects could get loans with lower requirement level of loan securities.

- The majority of managers interviewed agreed that asymmetric information problem can make credit gap between commercial bank and small business worse. A manager noted that the reliability of figures in the financial statements issued by small business was quite questionable. Most small businesses send their financial statements to commercial banks for loans without auditing. Moreover, the declaration and protection of business information were not clearly defined in law, so small businesses themselves felt unsafe and harmful when they showed the true stories of their businesses. Additionally, although financial statements were audited, the reliability of these audited documents was still a question for the bank managers. This can be explained that the auditing companies just approved the figures in financial statements, and when the third party such as bank using these documents for their decisions, but these figures didn't tell the real story of business performance. The responsibility of auditing companies were still abstract in law book, so it was so difficult for the third parties to ask for compensation because of their auditing faults caused by the competence or ethic of the auditing staff. In other words, an auditing company could audit financial statement for small business, but when the auditing fault occurred it had no reliability for third parties' losses. Moreover, in practice auditing services were so new and costly that very few small businesses could use this service. In this situation, although financial statement was approved by auditing companies, banks could not believe these figures, therefore most of banks asked small businesses for loan securities in term of collateral or guarantee before accepting loans, a manager explained.

\subsection{Quantitative Approach: Survey Questionnaire Development}

The preliminary questionnaire of the survey reflecting the credit constraint of small business in terms of loan success or failure was developed from the current theories, database publication and results from the structured interviews of local commercial bank managers and directors. The major contents of the questionnaire answered by small business managers and owners related to such following issues as property rights; quality of bank services; business cooperation with bank; equality in accessing bank finance; quality of business; transparency of business information; and bureaucracy of bank.

\subsection{Population and Sample}

The target population of research is small businesses with less than 50 employees that have been trading at least one year in Saudi Arabia. The intention of the survey was to collect data from a sample of small businesses considered to have transaction with local commercial banks. The research sample focuses on the private small businesses operating mainly in manufacturing, trading and service industries that have registered their businesses with the Chamber of commerce. The survey questionnaire is designed and sent to the owners and managers who involve in the investment project or in transactions with the local commercial banks for loans in the small businesses.

Basing on the list of private companies that are monitored by the Chamber of commerce, there were about 687 questionnaires to be distributed to the owners and managers of private small businesses in Saudi Arabia through 
email. Many emails were bounced back as perhaps may be the incorrect email address or old email address. Total 276 questionnaires collected were useable for the analysis, many questionnaires were discarded from analysis because these questionnaires were not fully completed or the major important parts of questionnaires were missed or the respondents blindly filled in the questionnaires without looking at the order and logic of the answers.

\subsection{Hypotheses Development and Regression Model}

In general, the credit constraint of small business sector could be measured by asking for direct number of loan application of small business accepted or rejected by the database of commercial banks or by looking at small business owner's report relating to the success or failure of loan application. However, in practice it is impossible to access such bank information related to the loan application's success or failure in Saudi Arabia, therefore the research uses an indirect measurement by looking at the perception of small business' owner concerning the failure or success of loan they have applied to the local commercial banks.

A regression model analysis is used to express the causal relationship between the credit constraint of small businesses, regarding as dependent variable and factors that hinder the possibility of small businesses in obtaining bank finance, regarding as independent variables. The credit constraint can be measured by small business owner's perception on the success or failure of loan application submitted to local commercial banks by small businesses. It means that dependent variable is designed in form of dummy variables with 1 for success of loan application and 0 for failure of loan application. Basing on current theories, two groups of hypotheses were developed and described below, including internal and external influential factors on the possibility of small businesses in obtaining bank finance. The first is composed of internal factors regarding to business cooperation with bank, quality of business and transparency of business information. The second concerns external factors, known as quality of bank services, bureaucracy of bank, property right, equality of credit access.

1. The better the business cooperation with bank, the higher the level of credit access for small businesses;

2. The higher the quality of business, the higher the level of credit access for small businesses;

3. The higher the transparency of business information, the higher the level of credit access for small businesses;

4. The simpler the determination of property rights with local authority agents, the higher the level of credit access for small businesses;

5. The higher the quality of commercial bank services, the higher the level of credit access for small businesses;

6. The higher the equality in accessing bank finance among different economic sectors in economy, the higher the level of credit access for small businesses;

7. The lower the bureaucracy of commercial banks, the higher the level of credit access for small businesses;

Together with two groups of hypotheses, a regression model was also developed:

$$
Y=\beta+\beta_{1} X_{1}+\beta_{2} X_{2}+\beta_{3} X_{3}+\beta_{4} X_{4}+\beta_{5} X_{5}+\beta_{6} X_{6}+\beta_{7} X_{7}
$$

Where:

Y: Failure or success of loan application submitted by small businesses to bank

$X_{1}$ : Business cooperation with bank

$X_{2}$ : Quality of business

$X_{3}$ : Property rights

$X_{4}$ : Quality of bank services

$X_{5}:$ Equality in credit access

$X_{6}:$ transparency of business information

$X_{7}$ : Bureaucracy of bank

To deal with a non-metric dependent variable, known as binary or category, it is suggested that a logit regression should be used rather than standard linear regression (Hair et al, 2010). This analysis process is described in details in the section of empirical analysis. 


\section{Empirical Analysis}

A factor analysis was performed to reduce the original set of variables and created a new set of variables in form of new factors. These new factors with eigen-value equal or greater than 1 were selected and named as property rights; quality of bank services; business cooperation with bank; equality in accessing bank finance; quality of business; transparency of business information and bank bureaucracy.

Table 1. Factor analysis

\begin{tabular}{lll}
\hline Construct Name & Explanation & Reliability \\
\hline Property right & $\begin{array}{l}\text { Extent to which respondents behave that property } \\
\text { right are well developed }\end{array}$ & .704 \\
Quality of ban services & $\begin{array}{l}\text { Extent to which respondents behave that quality of } \\
\text { bank services are well developed }\end{array}$ & .949 \\
Business cooperation & $\begin{array}{l}\text { Extent to which respondent behave that business } \\
\text { cooperation are well developed }\end{array}$ & .876 \\
Exuity in credit access & $\begin{array}{l}\text { Extent to which respondents behave that equity in } \\
\text { credit access are well developed }\end{array}$ & .779 \\
Quality of business & $\begin{array}{l}\text { Extent to which respondents behave that quality of } \\
\text { business are well developed } \\
\text { Extent to which respondents behave that } \\
\text { Information transparency are well developed }\end{array}$ & .737 \\
Bnformation transparency & $\begin{array}{l}\text { Extent to which respondents behave that bank } \\
\text { bureaucracy are well developed }\end{array}$ & .859 \\
\hline
\end{tabular}

Due to the binary or categorical dependent variable, 1 for loan success and 0 loan failure of small businesses, it is suggested that logistic regression should be used in order to examine the correlation between the dependent variable and independent variables in the regression model (Hair et al, 2010). In this process, the new set of variables mentioned in Table 2 was used as inputs for logistic regression in the second phase of analysis. The major results of the logistic regression, including the coefficient value, wald statistic value and significance test for difference of means of the regression model and results of hypotheses testing are organised in the Table 2.

Table 2. Logistic regression analysis

\begin{tabular}{llll}
\hline Variables & Coefficient & Wald statistic & p-value \\
\hline Business cooperation & .243 & 53.694 & $\mathbf{. 0 0}$ \\
Quality of bank services & .265 & 28.367 & $\mathbf{. 0 0}$ \\
Quality of business & .187 & 14.756 & $\mathbf{. 0 0}$ \\
Bureaucracy of bank & .230 & 11.270 & $\mathbf{. 0 0}$ \\
Property rights & -.064 & 1.232 & .23 \\
Business information & -.028 & .232 & .63 \\
Equality of credit access & -.171 & 3.770 & $\mathbf{. 0 5}$ \\
\hline
\end{tabular}

Property right: The result from analysis shows that there is no evidence to suggest that that respondents' perception of the effectiveness of property rights have a significant impact on the capability of small businesses to access bank finance ( $p>$.05). It means that the result doesn't support the hypothesis. This can be explained that not only business owners, but also normal asset owners have difficulty in registering their properties with local governmental agents, so there is no distinction between people who are great constrained and those who are not. In fact, the property rights, private ownership and asset transferring rights are defined and protected in law book. Moreover, the individual and business assets are freely transferred on the market, and the prices of assets are also determined by the market factors. The problems for property right registration take root from the administrative bureaucracy, and it could only be improved when local authorities apply a one-stop administration procedure in order to simplify this process. 
Quality of bank services: The test result shows a strong significance at level of p-value less than $0.01(.00)$. The evidence suggests that quality of bank services has a strong influence on the level of loan application success submitted by small businesses. In other words, the test result strongly supports the hypothesis. Further examination of the mean values of the variables that comprise overall quality of bank services shows that the credit officials have limited understanding of business in term of market and industry knowledge. And the banking services, such as type of loan or means of application are also limited. Small businesses have difficulty in accessing long-term loan for their growth expansion or technology innovation that requires a longer time to get back the investment capital. In addition, small businesses are also at disadvantage when bank evaluate their collaterals; therefore many of small businesses could not get enough fund for their needs because the real value of assets was far away from the evaluation value made by bank. In reality, small businesses face higher requirements of loan application documents and securities, but lower probability of loan approval that leads to the higher ratio of loan failure for small businesses. The result also suggests that it is likely that there is still an ideological gap of state commercial banks when dealing with small business loan application in terms of less amount of loan approved than applied and more documents required than necessary in compared with state or foreign-invested sectors.

Business cooperation with bank: the evidence from the test supports that the business cooperation with bank has an influence of on the success of small business loan application when the p-value is lesser than $0.01(.00)$. The result also strongly supports the hypothesis. It is recognised that the level of business belief on bank and versus are quite questionable. Further examination of the mean values of the variables which comprise overall business cooperation with bank recognises that small businesses do not believe in bank officials because they state that business information, such as information related to performance, investment or finance can be misused by credit officials and in this case that can harm small business benefits. It is clear that while the level of cooperation between two partners is low, the risk for loan failure and the cost for loan transaction are likely high. As a result, without fulfilling successfully requirements of loan security, small businesses fail to access bank credit.

Equality in credit access: As discussed above, there is likely to be an ideological gap in offering bank finance from the state commercial bank to small business sector in comparison with state sector. The result of test shows a significance on the equality in supplying bank credit for small business sector in comparison with other economic sectors in national economy, it is significant at level of p-value less than .05 (.05) and this result supports the hypothesis. It can be seen that small business sector is likely to have more difficulties in obtaining bank finance than other economic sectors. The inequality of credit access can be described by the high volume of loan failure or limited credit access in terms of higher loan security requirements, difficulty in obtaining long-term loans, disadvantage at collateral evaluation, longer time for loan evaluation procedure and less amount of loan acquired than business need.

Quality of business: The result showed that the quality of business had a strong impact on the success of small business in accessing bank finance. It is significant at level of p-value less than .01 (.000), and the result strongly supports the hypothesis. Further examination of the mean values of the variables which comprise overall quality of business suggests that such small businesses had high growth rate in both revenue and profit can have more opportunity to get the credit fund from bank. Furthermore, the debt-equity ratio in the capital structure of the business also had influence on the level of loan success, the lower the debt-equity ratio in the capital structure, the higher the probability of bank loan success. The result also shows that if the flow of information exchange between bank and small business was improved better, the chance for small business to access bank finance was higher. In other words, if bank had more information related to the business performance, especially accounting and financial information, the credit gap can be reduced between small businesses and commercial banks.

Transparency of business information: As discussed, information plays an important role in the success of loan transaction between small businesses and commercial banks. However, surprisingly there is no evidence from respondent's perception to suggest that the business information transparency had influence on the ability of small business loan application success. It means that the result doesn't support the hypothesis. This can be explained that the level of mutual belief between the commercial bank and small business is quite far, and the cost of information collecting for lending decision is also so high, so commercial banks have to apply a strict strategy of loan security toward small business, and this makes small business feel discriminated in accessing bank finance. Furthermore it is quite understandable for bank strategy that in an imperfect market in terms of lack of institutional market support, shortage of legal framework and asymmetric information problem, the bank have to reduce the risk for loan by requiring higher loan securities. Therefore, business information cannot play an essential role, regarding as an assurance in loan evaluation process. As a result, although small businesses that have a potential project and are willing to share their information with bank, without collaterals or loan guarantee their loan applications are rejected. 
Bureaucracy of bank: The result showed a strong significance of bureaucracy of bank on the success of small business loan application with p-value less than .01 (.001) and this result strongly supports the hypothesis. Further examination of the mean values of the variables which comprise overall bureaucracy of bank suggests that the procedure for loan application is so complicated and the application documents required are overlapping or unnecessary. In some cases, bank is not interested in the small business loan application and credit need. It can appear that when state commercial bank is obtaining 70 percent of market share in the credit market, and its main customer is the state enterprises. Together with soft budget constraint, the state commercial banks are likely to be reluctant to lend money to the small business sector, which belongs to the private sector in the economy. Therefore, the state commercial banks might require higher level of loan securities and more application documents from small businesses when compared to state sector. And the evaluation procedure usually lasts longer, but the amount of loan accepted is likely much smaller than the original value applied by small business.

\section{Conclusions}

This Research applied a mixed methodology in measuring the credit constraint of small business sector in Saudi Arabia. In the study, together with current theories, the qualitative data collected from the structured interviews of bank credit managers in the first stage is used to construct questions in the survey questionnaire of the second stage. In the sequential design, the results from the survey of small business owners and managers can provide a significant insight of credit constraint faced by the small business sector by reflecting the perception of both commercial bank and small business. The findings of study contribute not only the current theories, but also policy implication as well. Furthermore, the results of the study also help researcher produce a deeper and more reliable results in evaluating the nature of the credit constraint faced by small business sector in the credit market in transition economy.

The result of study shows that the levels of business cooperation and information sharing and quality of business have an important significance on the success of loan application. It is obvious that asymmetric information can make the credit gap worse. When the commercial banks have not enough information about small business or it is quite costly for collecting such information, the bank behaviour in this case is to require higher loan security that can lead to the higher failure ratio of loan application from small business. It can be said that the higher the level of business cooperation and information sharing and quality of business, the higher the level of loan success. Furthermore the result also supports that the bureaucracy of bank in terms of loan documents requirement and loan evaluation procedure can make small business hesitate when applying loan for state commercial banks. In addition, the high level of collateral requirement and the method of collateral evaluation are disadvantageous for small business. The bank credit officials' competence in terms of knowledge and understanding of the business market and industry are still limited so they cannot give useful advice or help the small business in case of need. Moreover, bank products are so plain in terms of types of loan that small business has limited choice to get credit loan, especially long-term loan. Finally, findings of study also indicate that it is likely in case of soft budget constraint, state commercial banks seem to hesitate lending to the private sector rather than state sector, and it appears that there is an ideological gap in manager's mind when deciding to offer loan to small business.

In conclusion, the findings from both quantitative and qualitative analysis support that the credit gap exists between small business sector and commercial banks in terms of technological and ideological contexts in Saudi Arabia. By using mixed methods with multiple data sources to measure the same problem of credit constraint, the findings of study can be more valid and reliable in case of better understanding of the credit gap in supplying credit for small business sector in an emerging economy. It is undoubted about the economic role of small business sector in transition economies; therefore basing on the result of study, it is likely to be wise for policy makers to make a change of the current situation of credit supply in forms of banking reform and governmental funding support in order to meet the credit demand of private sector, especially small businesses, and simulate the foundation and development of this sector in the national economy as a whole.

\section{Acknowledgement}

The researchers would like to thank the Deanship of Scientific Research at King Saud University represented by the Research Centre in the College of Business Administration for financially supporting this research.

\section{References}

Alain, F., \& Kiril, T. (2011). European Entrepreneurship in the Globalizing Economy. Edward Elgar.

Allen, J., \& Engert, W. (2007). Efficiency and Competition in the Canadian Banking. Bank of Canada Review, 37-50.

Aryeetey, E. (2008). Informal Finance for Private Sector Development in Africa. African Development Report, World Bank. 
Cressy, R. (2002). Funding Gaps: A Symposium. The Economic Journal, 11(2), 1-16. http://dx.doi.org/10.1111/1468-0297.00680

Cunningham, L. F., Clifford, E. Y., \& Moonkyu, L. (2000). Methodological Triangulation in Measuring Transportation Service Quality. Transportation Journal, 40(1), 34-47.

Hakim, C. (1987). Research design: strategies and choices in the design of social research. London: Allen \& Unwin.

Jane, S. P. (2003). Small firm finance and economic geography. Journal of Economic Geography, 3(4), 429-452. http://dx.doi.org/10.1093/jeg/lbg015

Jean-Charles, R., \& Jean, T. (2006). Two-sided markets: a progress report. The RAND Journal of Economics, 37(3), 645-667. http://dx.doi.org/10.1111/j.1756-2171.2006.tb00036.x

Joseph, F. H., William, C. B., Barry, J. B., \& Rolph, E. A. (2010). Multivariate Data Analysis (7th ed.). Prentice Hall.

Landier, A., \& Thesmar, D. (2009). Financial Contracting with Optimistic Entrepreneurs. The Review of Financial Studies, 22(1), 117-150. http://dx.doi.org/10.1093/rfs/hhn065

Michael Quinn Patton. (2001). Qualitative Research \& Evaluation Methods. Beverley Hills: Sage.

Muhsin, K., Saban, N., \& Huseyin, A. (2011). Financial development and economic growth nexus in the MENA countries: Bootstrap panel granger causality analysis. Economic Modelling, 28, 685-691. http://dx.doi.org/10.1016/j.econmod.2010.05.015

Silverman, D. (2002). Qualitative Research: Theory, Method and Practice. Sage.

Smallbone, D., \& Welter, F. (2001). The Disincentiveness of Entrepreneurship in Transition Economies. Small Business Economics, 16, 249-262. http://dx.doi.org/10.1023/A:1011159216578

Vos, E., Yeh, A., \& Tagg, S. (2007). The Happy Story of Small Business Financing. Journal of Banking and Finance, 31(9), 2648-2672. http://dx.doi.org/10.1016/j.jbankfin.2006.09.011

Webster, L. (1999). Small and Medium Enterprises in Vietnam: On the Road to Prosperity. MPDF, World Bank. 